\title{
El año 711: consecuencias tomadas como causas
}

\author{
Emilio GONZÁLEZ FERRÍN \\ Universidad de Sevilla, Estudios Árabes e Islámicos \\ ferrin@us.es
}

Yo invertiría la imagen establecida: sobre una pluralidad inicial, se abriría paso una posterior unidad. Josef van Ess ${ }^{1}$

\begin{abstract}
El relato de la conquista del noroeste de África y de España pertenece más a la tradición religiosa que a la historia.

Rachel ARIÉ ${ }^{2}$
\end{abstract}

\section{HIPÓTESIS FALSACIONISTA}

Las realidades complejas no suelen tener explicaciones simples. Sin embargo, durante siglos de tradición cronística y académica -en gran medida, escolástica-, el análisis de una realidad tan compleja como la forja de algo llamado Al-Andalus, ha necesitado entroncar las más frondosas ramificaciones de diversos saberes sobre la base de un solo hecho comúnmente admitido: la Península Ibérica debió de ser invadida en 711 por el Imperio islámico de Oriente, con capital en Damasco. La afirmación en sí requiere una obligada e inquebrantable fe historiográfica, porque los mil y un detalles sobre los que generaciones de arabistas y medievalistas han compilado sus exuberantes narraciones acerca del 711 -listas de nombres e interpretaciones sobre las que basar otras similares, ingente castillo de naipes creciendo en progresión geométricabeben todos, sin excepción, de fuentes documentales árabes compiladas, al menos, ¡siglo y medio después de los hechos relatados!

Este problema -la patente carencia de fuentes primarias y la indudable inducción literaria de fuentes secundarias muy posteriores- se presentó también, hace tiempo, a los estudiosos del Oriente islámico. Resultaba evidente que desde un supuesto acto fundacional del islam en 622 hasta las fechas que nos ocupan -primeros de los 700-,

1 J. VAN ESS, http://www.goethe.de/ges/phi/prj/ffs/the/a96/de8626506.html.

2 R. ARIÉ, España musulmana (siglos VIII-XV), Barcelona, 1984, p. 368. 
no había fuentes árabes, ni Corán escrito, ni prueba documental alguna en árabe de cuanto los libros de Historia dan por sentado basándose en crónicas árabes igualmente tardías. Dándole vueltas a cuanto esto puede implicar, el arabismo y medievalismo foráneo se ha apresurado a incluir infalibles cláusulas de salvaguarda en sus trabajos. Los estudios sobre las crónicas árabes orientales -así como todo el aparato formativo del Islam cultural y religioso-, aparecen, de este modo, enmarcados en advertencias que reflejan "menos cuanto ocurrió que cuanto los musulmanes, mucho después, quisieron que se recordase como lo ocurrido. Se trata de un aspecto convertido en punto de arranque interpretativo -al menos entre los académicos occidentales- desde los estudios pioneros de Ignaz Goldziher [...]"3.

Tales estudios foráneos clausuran -ipor fin!- la costumbre de confundir teología e historia; cuestionan la interpretación de un tiempo según requerimientos proféticos. Bien está respetar la verdad simbólica de textos considerados fundacionales por determinados dogmatismos religiosos; pero dista un trecho de ahí a contemplar historiológicamente tales textos como fuentes primarias, al ser compilados muy posteriormente al tiempo que pretenden remitir. Teniendo en cuenta que el citado pionero Goldziher murió en 1921, quizá ha habido tiempo ya para haberse tenido en consideración el monumental órdago que desde entonces se planteaba en el estudio de las fuentes culturales del Islam, probablemente interesantes para el estudio de su proyección hacia Occidente. Sin embargo, fieles -por una vez- al inventemos nosotros, el arabismo y medievalismo españoles -de común acuerdo, y sin que sirva de precedente- no juzgó oportuno darle vueltas a las cosas.

Lo cierto es que estriba ahí la base de un problema: que sean precisamente el medievalismo y el arabismo quienes se ocupen de los orígenes del islam y del Islam, cuando lo cierto es que tales orígenes podrían considerarse fuera del ámbito del medievalismo -ya que se remontan a la llamada Antigüedad Tardía; si nos ponemos convencionalistas y aceptamos fronteras en tiempos de transición ${ }^{4}$-, así como fuera del arabismo, ya que las únicas crónicas fiables están escritas en latín, griego, siríaco y algunas otras lenguas medio-orientales o incluso asiático-centrales -georgiano, armenio...-, pero en ningún caso en árabe.

En realidad, y a poco que nos paremos a pensar, no hay ninguna posibilidad lógica de establecer un 711 occidental invasivo sin depender de un simultáneo 711 oriental invasor. Por lo tanto, bien podríamos partir de qué estaba ocurriendo en Oriente por esa época para, de ese modo, conectar con cuando pudo o no ocurrir en Occidente. Veremos que, a poco que se abra la ventana y entre aire fresco, aquel citado castillo de naipes -aquel constructo minuciosamente salvaguardado por invasiones, turbantes y alfanjes-, mostrará su inconsistencia.

3 J.P. BERKEY, Formation of Islam: Religion and Society in the Near East, 600-1800, Nueva York, 2003, p. 59.

4 De hecho, larguísimo tiempo de transición. vid. K.G. HOLUM y H. LAPIN (eds.), Shaping the Middle East: Jews, Christians, and Muslims in an Age of Transition, 400-800 C.E. (Studies and Texts in Jewish History and Culture, 20), Bethesda, 2011. 
Las presentes líneas, como todo lo que llevamos escribiendo desde el año $2006^{5}$, no pretenden en modo alguno menospreciar esa ingente labor narrativa de arabistas y medievalistas españoles, sino contemplarla desde un punto de vista diferente. Probablemente, valorarla en su justa medida literaria, algo más que históricamente. Dicho de otro modo: los naipes siguen sirviendo, pero se muestran más firmes encartados que en su veleidad constructora. No es la nuestra una opción ideológica, sino de pura necesidad intelectual basada en la lógica de dos presupuestos: en primer lugar, que las ciencias no avanzan por mero acatamiento doctrinal, sino mediante el procedimiento de ensayo y error. En segundo lugar, que para comprender algo en su conjunto no sirven de gran ayuda los metalenguajes ni la obsesión taxonómica; la distribución jerárquica de disciplinas a modo de compartimentos estancos a la que aludíamos al dejarse en el tintero a crónicas no árabes previas, así como a acontecimientos históricos considerables como pre-medievales. Porque, a estas alturas, el dogma de un 711 institucionalmente conquistador árabo-islámico solo es posible mediante el empeño de no mirar a los lados; el encastillamiento en las especialidades propias, en los objetos de estudio aislados y descontextualizados.

Puesto que tratamos con la historia, con el tiempo en marcha, podemos resumir que su esencia es el movimiento. En otra parte hemos descrito el proceso de interpretar los acontecimientos pasados como el esfuerzo por tomar la fotografía de un caballo al galope, montando el fotógrafo otro caballo en similar galope. Dos movimientos en intento de coordinación: el movido tiempo que tratamos de describir, y el presente en movimiento desde el que tratamos de enfocar. Por lo mismo, transición en marcha frente a esfuerzos de continuidad será una tónica dialéctica de mayor relevancia que el mero relatar de fechas/aduanas, siempre coloreadas a posteriori.

Por otra parte, aquel reparto de competencias entre disciplinas a modo de compartimentos estancos debe desestimarse por su simpleza distributiva en aras de un más complejo requerimiento historiológico: todo punto de vista disciplinar exclusivista está descartando y alejando de su objetivo innumerables detalles necesarios para una más completa comprensión de la cosa. Teología y literatura, ésta y el arte, la historia que dejan ver entretanto, abrazadas todas por mil y un saberes auxiliares, se entremezclan sin remisión para ofrecer una imagen fiable del tiempo que nos ocupa o interesa. Tiempo, todo sea dicho -y por volver a lo de antes-, que no entiende de etiquetados inamovibles al estilo de ";Usted!: deténgase al finalizar la Antigüedad Tardía, que ya me ocupo yo de la Edad Media...".

Resulta evidente que un procedimiento historiológico, un deseo de comprensión de los mecanismos de la historia, conlleva cierto escepticismo con respecto a verdades universalmente admitidas -por no hablar de actitudes autoritarias-, así como un permanente descubrimiento de ignorancias propias: si -pongamos por caso- provenimos de una formación en historia del arte y debemos internarnos en cuestiones literarias llevados por el curso de nuestra búsqueda, indudablemente pisaremos cada vez con más cuidado a medida que avancemos. La paradoja de la historiología es que parece deber casar independencia de criterio con visión de conjunto, entrando en colisión

5 E. GONZÁLEZ FERRÍN, Historia General de Al-Andalus. Europa entre Oriente y Occidente, Córdoba, 2006 ( $4^{\mathrm{a}}$ edic., 2010). 
con un viejo y certero dicho: "quien mucho abarca, poco aprieta”. Bien: en ocasiones, a lo largo de una verdadera y honrada búsqueda interpretativa, el investigador debe renunciar a llevar la contraria al refranero y asumir, sin más, que sus hipótesis de conjunto jamás podrían vestirse de colección dogmática hiper-especializada; que deberá abarcar al precio de no apretar.

Con todo, siempre se podrá argumentar que tal refranero tampoco especifica prioridades y que, al cabo, el refrán citado no es menos cierto que su contrario. Es decir, que quien mucho aprieta, poco abarca, sin que se aclare a ciencia cierta qué es mejor, abarcar o apretar.

$$
* * *
$$

De entrada, compartimos la consideración del científico como artista, en tanto debe proponer teorías propias basándose en materiales comunes. Resulta de un mismo modo vana y vanidosa la usual aspiración -mandarina y corporativa- a que la ciencia deba alcanzar una definitiva explicación unitaria. Es esta aspiración, precisamente, la célebre herida narcisista localizada en los viejos debates epistemológicos en torno a la llamada hipótesis falsacionista en las ciencias; en la medida en que se pretende ingenuamente cerrar cuestiones históricas como si de cicatrices se tratase ${ }^{6}$, en lugar de mantener abiertas las posibilidades de nueva luz sobre acontecimientos pasados. Al margen de etiquetados o preferencias, nos parece adecuado precisamente este método, el falsacionismo, por cuanto su procedimiento consiste en la poda sistemática de falsedades; supercherías comúnmente admitidas, cuya consideración ya ideologizada pide a gritos un cambio de paradigma, a menos que se busque precisamente confundir la narración histórica con la elaboración de constructos.

\section{EL ENORME PARADIGMA}

La narración canónica de la conquista islámica de Al-Andalus en 711, tal y como fue redactada en árabe a partir de 850, es uno de los primeros esbozos literarios de un género creado en Egipto, el de los futuh, o crónicas de conquista. No nos detendremos nuevamente en el posible e interesante escorzo de inter-textualidad que requeriría la genuina puesta en valor literaria de unas obras mal tomadas por fuentes historiográficas primarias. Ya hemos aludido a ello en otros lugares ${ }^{7}$, y basta ahora un somero repaso temático para dar una idea de esos elementos de literatura comparada:

- El parecido razonable entre la ruta de Tariq y Musa y otra anterior: la intervención del ejército bizantino en torno a los 550, desde Cartagena, para salvaguardar Spania -denominación de la Península Ibérica bajo control bizantino, en la franja costera sur-oriental- frente a Hispania. Esa expedición bizantina -oriental, desde Cartagena,

\footnotetext{
6 A. KAULINO y A. STECHER, Cartografía de la psicología contemporánea. Pluralismo y modernidad, Santiago de Chile, 2008, p.139.

7 Por ejemplo, E. GONZÁLEZ FERRÍN, “Al-Andalus: del mito asumido al Renacimiento", Miscelánea de Estudios Árabes y Hebraicos (Sección Árabe), 58 (2009), pp. 383-405.
} 
insistimos; el lógico lugar de desembarco viniendo desde Oriente, la vieja ruta de Cartago a Cartago Nova- fue tradicionalmente asociada con el comandante Liberio, pero tal protagonismo ha sido cuestionado últimamente ${ }^{8}$ sin que ello plantee dudas acerca de la intervención en sí.

- Lo oportuno de la onomástica: con un conquistador Tariq -que significa el que abre camino- y un anciano y barbicano Musa que es Moisés en árabe; el que atravesó el mar guiando a su pueblo, hecho que habrá que poner en relación con la difícil delimitación inicial entre lo proto-islámico y lo judío, ambos en expansión mediterránea por conversión entre una selva de mil y una heterodoxias cristianas. Entraríamos ahí en un precioso juego inter-textual teológico en el que no están dispuestas a participar tres ortodoxias religiosas concretas.

- El culebrón de la invasión por rapto de doncella -Don Julián y la hija de Don Rodrigo- en homenaje intertextual a la excusa en el arranque narrativo de la Ilíada con la huida de Helena y la invasión organizada en venganza.

- El injerto del reino oriental en Occidente: del último troyano fundador de Roma -Eneida de Virgilio-, al último omeya fundando el Emirato.

- Las peripecias de los Diez Mil, desde la Anábasis de Jenofonte a los diez mil sirios de Balch sosteniendo al primer Omeya de al-Andalus.

Por otra parte, resultarán igualmente significativos dos tipos de errores comúnmente pasados por alto:

- Errores de sinonimia en la denominación: la inveterada costumbre de traducir por musulmanes cada vez que aparezcan caldeos, sarracenos, árabes, agarenos, ismaelitas y tantos más en crónicas previas no árabes que, según veremos, son las verdaderas fuentes primarias de cuanto pudiese ocurrir en el tiempo y espacio que nos ocupa.

- Un craso error doble de anacronismo: pensar que los moros son los musulmanes: mauri serían los negros, sin más, para crónicas griegas, bizantinas, muy anteriores al Islam. Por otra parte, un error similar es pretender que los bereberes sean los hombres azules del desierto, recién convertidos en musulmanes poco antes del 711. Por contra, los barbaroi y el barbarus del griego y el latín -albacora del término bereber en árabe- son, sin más, los no helenizados ni latinizados, desde los enemigos del emperador bizantino Heraclio en la primera mitad de los 600, hasta la inmensa y variopinta mayoría de un norte de África, comprimida y liofilizada en las crónicas árabes -muy posteriores- para convencimiento de una especie de efecto dominó, con frenética entrega de llaves de ciudades a las caballerías milagrosas de Oriente.

$* * *$

La referida inter-textualidad arroja un dato historiológico de esencial consideración: todo ese entorno cultural helenístico de cuyas semillas brotarán las crónicas árabes -entorno greco-latino en su máxima extensión, por cuanto Bizancio representa a la perfección esa simbiosis-, es el barbecho sobre el que surgen tanto el islam

8 J. J. O’DONNELL, “Liberius the Patrician”, Traditio, 37 (1981), pp. 31-72. 
-religión- como el Islam -civilización-. Ello nos lleva, indefectiblemente, a la consideración del llamado tiempo omeya oriental como el de un Islam helenístico en avanzada fase de arabización desde abajo -masas árabes sin alfabetizar- y leve arabización desde arriba -escasas monedas e inscripciones-, al igual que el tiempo abbasi -verdadero espacio cronológico de eclosión islámica- implicará la arabización definitiva -Bagdad- de un impulso civilizador sasánida; de amplia desembocadura persa en el Mediterráneo.

Evidentemente, en todo esto hay latente una interpretación bastante compleja de cuanto pudo azotar al Mediterráneo oriental, sur y occidental, desde los primeros años 600 a los 850 , una época de brumas historiográficas tan destacables que insinúa un extendido abanico de catástrofes inexplicables e inconexas. Solo una lectura posterior convertirá en progresión lineal e inducida lo que surgió como incertidumbre.

Dicho esto, ¿por qué se mantiene, pues, el constructo de un islam creacionista que provocó el repentino surgimiento de un Islam civilizador, de infalible avance hasta Hispania en 711? Porque, al fin y al cabo, existen varias ventajas en la interpretación de una fulgurante invasión islámica desde Poitiers -en Occidente- hasta el Amur Daria -en Oriente-.

- Se ofrece una razón exógena para el continuado desgaste de un área geopolítica -el Oriente Medio y Asia Central- sometido a siglos de cruentos enfrentamientos entre dos Imperios: Bizancio y la Persia Sasánida.

- Asimismo, y desde el punto de vista religioso tradicionista, se ofrece igualmente una oportuna lectura aséptica y alienígena del islam: que surgió de las dunas y las palmeras, emergiendo desde un extraño paganismo prácticamente enoteísta y de cacofonía judeocristiana por efecto de los ecos del desierto, cuando lo cierto es que el islam es un fenómeno eminentemente urbano y continuista, que dará paso a un Islam igualmente urbano y comercial ${ }^{9}$. Ello decanta dos tradiciones dogmáticas de una sola tacada: por una parte, el natural discurrir del monoteísmo judeocristiano como judío y cristiano, en distribución paralela por el Mediterráneo -uno por genética, otro por pacífica evangelización-, y por otra parte, nos presenta la irrupción del islam en la historia por requerimiento profético y a través de las armas. Siempre hemos considerado una falacia muy útil la consideración de una determinada tradición judeocristiana exclusiva. Cuando Boyarin presentó su imprescindible ejercicio intelectual de ruptura de rupturas en lo judeocristiano, ámbito siempre común con difusas lineas fronterizas -las border lines de Boyarin, a cuyo estudio animamos calurosamente ${ }^{10}$ - nos sorprendió que no se considerase la igualmente difusa borderline de lo judeoislámico y su distribución por el Mediterráneo igualmente por conversión, algo que últimamente tiene en cuenta David Abulafia -que el judaísmo se expandió por conversión, y que constituyó una suerte de islam alternativo, al igual que el islam debería considerarse como judaísmo alternativo ${ }^{11}$.

9 M. LOMBARD, L'Islam dans sa première grandeur (VIII'-XI ${ }^{e}$ siècles), París, 1987 (1ª edic., 1971), p. 208.

10 D. BOYARIN, Border-Lines: the Partition of Judaeo-Christianity, Filadelfia, 2006.

11 D. ABULAFIA,"Mozárabes, Mudéjares, Marranos, Moriscos. Las religiones de España en contacto y en crisis" en E. GONZÁLEZ FERRÍN (ed.), Al-Andalus: paradigma y continuidad, Sevilla, 2010, pp. 79 y 102. 
- En otro orden de cosas, el invasivo 711 ofrece otra no menos adecuada ni menos exógena razón utilitaria: el natural discurrir visigodo en la Península Ibérica continuó -en no menos natural transición desde lo romano, y obsérvese cómo esos pueblos se sustituyen deportivamente, como en un juego de relevo-, hasta que se presentó la gran cesura, el desastre sobrevenido del 711. Una invasión resuelve de un plumazo todo un ramillete de posibles causas de disolución de la monarquía visigoda.

- Por último, el utilitario 711 se presenta inamovible porque una conquista justifica una reconquista. El medievalismo tiene en gran y alta estima el reismo -reconquista, restauración carolingia, y glorioso final renacentista-, pero muestra demasiado a menudo el plumero ideológico y juega en todo momento con la ventaja de conocer el final del capítulo. Es probable que podamos circunscribir los orígenes de la reconquista a, precisamente, reconquistar lo que conquistó -y valga tanta redundancia- Almanzor en torno al año 1000, fechas interesantísimas -al margen del milenarismo evidente- para comprender el sentido de causa común de los reinos cristianos del norte. Sin embargo, es más útil ideológicamente desempolvar mitos muy anteriores -Covadonga- para dar carta de antigüedad a hechos posteriores. Es muy común la pátina ideológica preferencial en los acontecimientos históricos del largo y orgánico tiempo andalusí, pero el final conocido de 1492 retroalimenta todo el cromatismo de lo anterior.

Y, como muestra, un botón: el magnífico concepto de paz improbable acuñado por Ladero Quesada tras la conquista castellana de Sevilla en 1248 -tiempo de fronteras ${ }^{12}$ - juega, por ejemplo, con el imaginario de ideología reconquistadora. ¿Cómo es posible ese parón reconquistador desde mediados de los 1200 hasta finales de los 1400? Claro, es una paz improbable si se considera Sevilla solo como capitulo hasta Granada en una historia cuyo final conocemos. Pero, ¿y si Sevilla fuera un objetivo en sí, sin más? ¿y si su conquista fuera más bien de lógica ampliación geopolítica castellana -grandes contingentes de musulmanes que participaron quizá no lo habrían hecho en otros términos-? Pero no, la ideología de una reconquista tiene que animar la historia de esa gran alienación andalusí que, por lo mismo, debe comenzar en desastre sobrevenido desde fuera en forma de conquista árabo-islámica.

Este enorme aparato paradigmático se ha blindado a lo largo de décadas frente a determinadas interpretaciones alternativas sobre la génesis tanto del islam como del Islam; interpretaciones basadas en pruebas o ausencia de ellas, y no en convencionalismos atados a la extrañeza profética de una alteridad -visión orientalista, veíamos- o en la excepcionalidad creacionista de un mundo nuevo para los elegidos -visión emic del islam-. Es decir, existen numerosas explicaciones racionales de los hechos, que contrastan tanto con las hagiografías islámicas -desde dentro- como con las interpretaciones orientalistas -desde fuera-. El mito blindado consiste precisamente en un Islam -civilización, imperio, cultura- como la natural consecuencia del islam -religión revelada-, en tradicional aplicación de la célebre matriz islámica descrita por Von

12 M.A. LADERO QUESADA, "Sobre la evolución de las fronteras medievales hispánicas (siglos XI a XIV)" C. de AYALA MARTÍNEZ et alii (eds.), Identidad y representación de la frontera en la España medieval (siglos XI a XIV), Madrid, 2001, pp. 5-50. 
Grunebaum en su lectura de una -decíamos- alienígena identidad cultural del islam ${ }^{13}$ : que un profeta ofrece un Libro que describe una determinada visión del mundo que, a su vez, habla de tal modo a las masas próximo-orientales, que sobran años para su belicísima expansión por el mundo.

\section{EL ESTADO DE LA CUESTIÓN}

Tendremos en cuenta ahora las aportaciones en el ámbito del llamado Early Islam, el islam originario del que sin duda debe emerger lo considerable como un 711 invasivo posterior, por aquello de que no suele haber efecto sin causa. Procedemos -no podía ser de otro modo- mediante la lectura científica de una serie de acontecimientos, dejando para el ámbito de lo poético/sagrado y de lo ideológico toda otra interpretación no sustentada en pruebas. Es decir, para llegar al 711 hispano partimos de un Oriente cuya historia puede y debe des-teologizarse y des-ideologizarse, dado que cuanto viene considerándose como hechos incuestionables no cuentan, en realidad, la historia de un proceso, sino la justificación del tiempo inmediatamente posterior, en lectura eminentemente religiosa e ideológica.

A vista de pájaro, podemos considerar el gozne entre la Antigüedad Tardía y la Edad Media en el Mediterráneo y Oriente Medio fundamentado documentalmente en crónicas que se dividen en dos grandes grupos, en función de su tiempo y objetivo temático: aproximadamente entre los años 600 y 700 florecen de un modo inusitado las crónicas apocalípticas -latín, griego y siríaco principalmente-, para desembocar en las crónicas árabes desde mediados de los 800, como expresión de un salvífico Éxodo, con la conquista como expresión histórica de un requerimiento coránico. Así, desde un punto de vista historiológico -filológico/histórico/lógico-, y en la zona que nos ocupa, el sístole y diástole que bombea los orígenes de la Edad Media sería un sustrato historiográfico describiendo el fin del mundo conocido, para desembocar en un remake árabe de historias de salvación. Es precisamente esa teología del triunfo la que anima el arranque cronístico árabe desde los 800: han caído todos los poderes, ganan los pueblos -y ya se recuperará, a beneficio de inventario, como el imparable avance de la espada de Dios-.

Teniendo en cuenta el final de la historia conocida -califatos en torno a Córdoba, El Cairo y Bagdad, expansión del árabe, enfrentamiento medieval entre la Cristiandad y el Islam...-, no se ha entendido como necesario estudiar una época desligada de cuanto conocemos de su tiempo posterior, y así se ha procedido a la convencional redacción de cuanto Von Sivers denomina versiones seculares de una Vulgata ${ }^{14}$. Tal Vulgata es la interpretación al uso que fundamente un dogmatismo secular interpretativo en otro dogmatismo religioso. Dicho de otro modo: se considera que el Islam nace del islam, y que ambos -civilización y religión- son uno desde aquel Tiempo Magno mediní y mequí, avanzando por la Historia como un tornado, una suerte de

13 G. E. VON GRUNEBAUM, L'Identité culturelle de l'Islam, París,1973.

14 P. VON SIVERS, "The Islamic Origins Debate Goes Public", History Compass, 1 (2003), p. 3. El estado de la cuestión que presenta Von Sivers nos sirve de soporte argumental aquí. 
trompo cuya punta de acero -en movimiento absolutamente inducido desde dentroorigina su trayectoria en Medina y se desplaza hacia Meca, Jerusalén, Damasco, Bagdad, Samarcanda, Estambul...

Sin embargo, no debería confundirse lo dogmático religioso con la historia, y encima constituir sobre ello otro dogmatismo, esta vez pseudo-científico. Resulta evidente que el Islam no nace en Medina o Meca, sino en la frontera en llamas que unía -o separaba, según se mire- el Imperio Romano -posteriormente identificable con Bizancio- y la Persia Sasánida. Sobre los efectos de tal enfrentamiento en Oriente Medio y Egipto ya se ha escrito sobradamente, si bien cabe destacar aquí dos aspectos esenciales: la exuberancia de crónicas cristianas -de todo corte sectario- que entienden llegado el fin del mundo ante el envite de Persia sobre el Próximo Oriente -conquistas de Jerusalén (614) y Alejandría (621)-, así como la repentina desmovilización de tropas afines a uno u otro bando tras la batalla de Nínive (627), con el resultado de una pírrica victoria bizantina que desestabilizó el orden sasánida y replegó a una exhausta Constantinopla.

Cuando nómadas, sarracenos, árabes o tropas desligadas de mando único -ya sea persa o romano- campen por sus respetos haciendo suyas rutas caravaneras y ciudades enteras, los cronistas no expresan que sea un poder único el que les ataca, solo saben por qué lo hacen -el fin de los tiempos está cerca, la culpa la tienen los pecados de Calcedonia-, y lo conciben como lógica continuación del previo avance persa. No entraremos aquí en la enmarañada situación teológica en torno a determinados concilios: lo importante no es lo que rece o deje de rezar la gente; lo importante es que un dogmatismo, una herejía, la implantación novedosa de una ortodoxia, o la natural inercia de creencias posteriormente considerables como heterodoxia, están configurando un peculiar mapa del Mediterráneo sur y Oriente Medio. Garth Fowden ya puso de manifiesto la relación entre religiones de llamada universal, real o imaginaria y la super-estructura previa -en cierto modo ecuménica- del mundo sasánida ${ }^{15}$.

Nosotros entendemos esta relación como el genuino origen del Islam, ejemplificado en la construcción de una ciudad persa de corazón y lengua ya árabe -Bagdad, 762-, denominada madinat al-salam, la ciudad de la paz, como cierre de un tiempo determinado y simbiosis generativa de la civilización islámica. Los cronistas -ya árabes-, a partir de ese momento, se afanarán en establecer lazos legitimadores con Meca y Medina, pasando inevitablemente por Damasco. Pero, ¿realmente es Damasco un lógico precedente para Bagdad, o solo nos hemos acostumbrado a comprenderlo así por comodidad de secuencia cronológica? Porque, podría concebirse Bagdad como la radical alternativa persa a un orden de cosas helénico. A partir de ahí, la necesidad de legitimación mequi y mediní de ese Islam bagdadí -que si nos llamaremos Abbasíes por aquel Abbás tío del Profeta...- dice más sobre la expansión de la religión islámica que sobre la inducción histórica que tensó la cuerda desde Medina hasta Bagdad, pasando por Damasco. Esa cuerda, más bien parece una necesidad legitimadora.

15 G. FOWDEN, Empire to Commonwealth: Consequences of Monotheism in Late Antiquity, Princeton, 1993, cap.3. 
En ese orden de cosas, reflejado en el dictado de las primeras crónicas árabes, ¿cómo interpretar lo que pudo haber pasado casi un siglo antes, a miles de kilómetros hacia Occidente, en Hispania?

$* * *$

En el epígrafe siguiente saldrán ejemplos de lo diverso -a tenor de cuanto arrojan las crónicas pre-árabes- comprendido posteriormente como unitario. Valga ahora simplemente una alusión a cuanto se ha movido la interpretación del hecho islámico y el hecho coránico a la luz de la puesta en cuarentena de muchos convencionalismos creacionistas. Entendemos como falacia utópica la consideración de que una pequeña comunidad -Medina- pueda sentar las bases de una civilización que acabó organizando la vida de más de medio Mediterráneo. Sobre el constructo de una medinización que en realidad es una bagdadización no nos extenderemos mucho más aquí, por haberlo hecho ya en otro sitio ${ }^{16}$, pero sí debemos aludir a una larga tradición de estudios al respecto que normalmente han pasado prácticamente desapercibidos -si no despreciados- por el arabismo y medievalismo españoles. Y no sin razón, por otra parte, dado que se escapa por completo a su campo de estudio y no existe en España una islamología a tener en cuenta como comunidad científica -pese a su prestigio en el pasado; los tiempos de los padres Asín y Pareja-. Y estas cuestiones debían ser objeto de estudio de esa especialidad, la islamología.

Por contraste, la larga lista de islamólogos foráneos que cuestionan la validez de fuentes árabes en la historiografía del islam primigenio no es indicativa de su consideración en tanto que comunidad y/o escuela, ya que desde aquellas albacoras relativistas del citado Ignaz Goldziher a principios de los 1900, hasta la ideologización extrema del supuesto Christoph Luxenberg en el $2000^{17}$, la cosa avanza en un enfrentado ensayo y error lleno de matices, hasta el punto de ser ya considerado todo el asunto como una serie de batallas en la retaguardia, cuando el frente queda desabastecido. En ese frente, la verdadera batalla estriba en si deben tenerse en cuenta o no las fuentes árabes, tan alejadas de los hechos descritos, para fundamentar una seria historiografia del Islam primigenio.

El abanico de posturas -magníficamente fijado por Mulder y Milo en $2009^{18}$ - es correlativo con el desprecio olímpico hacia sus autores desde España y nuestros agudos pies de página, pero deberíamos tener en cuenta algunas ideas de cierto y ya nada corto predicamento: que si el islam surgió como mesianismo judeocristiano desde dentro y no necesariamente invasivo -Hégira como éxodo- (Crone y Cook $\left.{ }^{19}\right)$; que si debemos tener en cuarentena la propia existencia del fundador profético $\left(\mathrm{Nevo}\right.$ y $\left.\mathrm{Koren}^{20}\right)$;

16 E. GONZÁLEZ FERRÍN, "Medinización: Tres movimientos, tocata y fuga", J.A. GONZÁLEZ ALCANTUD (ed.), La ciudad magrebi en tiempos coloniales, Barcelona, 2008, pp. 232-240.

17 (Es seudónimo) C. LUXENBERG, The Syro-Aramaic Reading of the Koran: A Contribution to the Decoding of the Language of the Qur'an, Berlín, 2007 (original alemán $1^{a}$ edic., 2000).

18 E. MULDER y T. MILO, De Omstreden Bronnen van de Islam <Las refutadas fuentes del Islam>, Zoetermeer 2009, [tr. parcial en inglés, Sandra Heijden].

19 P. CRONE y M. COOK, Hagarism. The Making of the Islamic World, Cambridge, 1977.

20 Y. D. NEVO y J. KOREN, Crossroads to Islam: The Origins of the Arab Religion and the Arab State, Amherst, NY, 2003. 
que si islam surgió de unas aguas revueltas de un entorno sectario (Wansbrough ${ }^{21}$ ), las mismas que muchos otros movimientos religiosos considerados herejías; que si debemos prestar más atención al elemento compositivo siríaco -himnos cristianos- en la propia redacción del Corán -o, al menos, en su puesta por escrito (Lüling ${ }^{22}$ ); que si la forja de una tradición lineal se corresponde con un necesario aval mediní para el surgimiento del Chiismo en Irán (Madelung ${ }^{23}$ ), en realidad un fenómeno histórico absolutamente diferenciable y relacionado con el mesianismo judeocristiano iranio (Wasserstrom y los isawies $^{24}$ ); que si es imposible rastrear evidencia arqueológica alguna acerca de Meca a principios de los 600 (Hawting y Conrad ${ }^{25}$ ); que si todas las batallas relatadas en las crónicas árabes son estereotipos de necesaria comparación literaria $\left(\mathrm{Noth}^{26}\right)$; que si el califato es un genial invento posterior al 750 -dejando fuera, por lo tanto, a todo el etéreo tiempo omeya oriental $\left(\mathrm{Schacht}^{27}\right)$ - etcétera.

En líneas generales, de todo ese citado abanico de posturas cabe destacar en primer término que los orígenes del islam y del Islam han recibido numerosas nuevas luces desde la esclerotizada visión doble tanto orientalista -el Otro surgido del hormiguero de Arabia- como esencialista -requerimiento profético-. Luces que, sin lugar a dudas, arrojarán alguna que otra sombra o ligera matización sobre cuanto pudo pasar en Occidente, dependiente de un algo asumido ya como existente en Oriente. Como nota final a este estado de la cuestión, debemos aclarar que nos resulta admirable el enorme esfuerzo intelectual desplegado en todas esas interpretaciones y las reacciones contrarias -aquellas batallas en la retaguardia-. Por otra parte, no hay que compartir todos y cada uno de los enunciados para reconocer que en sus manos y páginas está la vanguardia de la islamología actual. El caso de alguno de esos autores es especialmente relevante: compartimos con Cook y Crone, por ejemplo, sus apreciaciones acerca de cuanto denominan la narrativa de los orígenes islámicos: una reconstrucción sin contenido histórico concreto ${ }^{28}$. De Crone también destaca su percepción del indigenismo no necesariamente invasivo del Islam. Por último, compartimos también sin fisuras la utilización del concepto de simbiosis creativa en Wasserstrom, así como nos parece sumamente fiable el concepto de poligénesis islámica, emanando de ese entorno sectario de Wansbrough, rompiendo así con aquel inveterado esencialismo

21 J. WANSBROUGH, The Sectarian Milieu: Content and Composition Of Islamic Salvation History (trad. y notas Gerald Hawting), Amherst NY, 2006 ( $1^{\mathrm{a}}$ edic., 1978).

22 Probablemente, el autor más castigado de todos los aludidos, tanto académicamente como en el monumental ninguneo de sus aportaciones. Vid. G. LÜLING, A challenge to Islam for Reformation: the Rediscovery and Reliable Reconstruction of a Comprehensive Pre-Islamic Christian Hymnal Hidden in the Koran under Earliest Islamic Reinterpretations, Nueva Delhi, 2003. Existe una traducción al español, aún no editada, obra de Ilya Topper.

23 W. MADELUNG, The Succession to Muhammad: A Study of the Early Caliphate, Cambridge, 1997.

24 S.M. WASSERSTROM, Between Muslim and Jew. The Problem of Symbiosis under Early Islam, Princeton, 1995, pp. 93 y ss.

25 G.R. HAWTING, "The Origins of the Muslim Sanctuary at Mecca", G.H.A. JUYNBOLL (ed.), Studies of the First Century of Islamic Society, Carbondale, 1982, pp. 23-47; L.I. CONRAD, "Abraham and Muhammad: Some Observations apropos of Chronology and Literary Topoi in the Early Arab Historical Tradition", Bulletin of the School of Oriental and African Studies, 50 (1987), pp. 225-240.

26 A. NOTH, The Early Arabic Historical Tradition: A Source-Critical Study, Princeton, 1994.

27 J. SCHACHT, The Origins of Muhammadan Jurisprudence, Oxford, 1950, pp. 191 y ss.

28 P. CRONE y M. COOK, op. cit; 1977, p. 3. 
islámico -para propios y ajenos-, y asumiendo por fin que el verdadero problema científico en toda esta cuestión consiste en no saber separar teología e historia.

\section{LA HIPÓTESIS DE LA RECAPITULACIÓN}

Suliman Bashear pone en cuarentena las crónicas árabes, en tanto que necesidad de legitimación posterior de unos pueblos nacidos en un ambiente de inseguridad apocaliptica $^{29}$. Probablemente sea un modo bastante pausado de describir cuanto pudo pasar en aquel larguísimo tiempo de transición citado. Decíamos antes que, en torno al 711, cuanto viene considerándose como hechos incuestionables no es, en realidad, la historia de un proceso, sino la justificación del tiempo inmediatamente posterior. Es decir, deberíamos poder leer cuanto pudo ocurrir -y así se nos ha transmitido en fuentes primarias, no en las árabes- desde comienzos de los 600 hasta bien entrados los 700 sin tener en cuenta lo que vino después. Uno de los principales problemas de la Historia -ya aludido- es que sabemos ese después de las cosas analizadas, y ello puede llevarnos a lecturas inducidas que confundan capítulos previos con causas, opciones históricas -unas concretas, entre otras tantas posibles- con determinismos proféticos.

Lo cierto es que, sin recurrir a lecturas inducidas desde relatos muy posteriores, la consideración invasiva, voluntaria y genérica del Islam se fundamenta en un constructo anterior apocalíptico cristiano pre-medieval, siempre ajeno, en todo caso, a la existencia de un algo denominable Islam en toda regla. Previo también a crónicas árabes que se harán eco de ese constructo, por cuanto servirá de legitimación de un poder ya establecido con voluntad de centralizador. Tal consideración se forja progresivamente, desde la sorpresa pre-mahometana del desmembramiento imperial romano iniciado en torno a los 400 de nuestra era, hasta la ya fehaciente consideración histórica del Islam como civilización en torno a la fundación de Bagdad (762).

Compartimos la idea de Tolan en el sentido de que tanto la imagen que Occidente se hace del Islam, como el relato de cuanto pudo o no constituir exactamente los primeros momentos de su contacto, consisten básicamente en la traslación de una ruptura psicológica posterior para ubicarla como ruptura física previa: la evidenciada diferencia medieval del Occidente cristiano con el Islam -ruptura psicológica- se reconstruye en sus orígenes como obligada ruptura física previa. Tal ruptura adquiere la útil forma de una invasión ${ }^{30}$. En realidad, no faltan materiales para sustentar la hipótesis de un desastre general sobrevenido en el tiempo que se considera como de cesura entre la Antigüedad Tardía y la Edad Media. Será Jean Flori quien acuñe el concepto de recapitulación para una técnica cronística al uso en toda esa

29 S. BASHEAR, Arabs and Others in Early Islam, (Studies in Late Antiquity and Early Islam, 8), Princeton, 1997. Existe una meritoria versión en árabe del mismo autor: S. BASHEAR, Introducción a la Otra Historia: hacia una nueva lectura de la narración islámica, Jerusalén, 1984. El autor emplea riwaaya para narración (novela, constructo narrativo). Bashear fue defenestrado -literalmente- durante una de sus clases en la Universidad de Nablús, por planteamientos tales.

30 J. TOLAN, Sarracenos: el Islam en la imaginación medieval europea, Valencia, 2007, pp. 30 y ss. 
corriente historiográfica aludida como albacora de lo islámico sin aún saberse tal. Cuando antes describíamos el sístole y diástole de la cronística proto-islámica, repartíamos la documentación entre encendidas descripciones apocalípticas -primera fase, en griego, latín y siríaco principalmente, veíamos-, y actualizaciones estereotipadas de un éxodo trasladado ya al árabe -segunda fase, triunfal retroalimentación legitimista abbasí oriental y omeya occidental-.

Pues bien, esa recapitulación teórica para Flori consiste, precisamente, en atribuir a una única y misma profecía varias realizaciones sucesivas en la historia ${ }^{31}$; establecer una linealidad histórica artificial y mítica a cuanto se produce en variado y progresivo abanico de circunstancias, punto éste en que debemos recurrir a las crónicas a mano. A bote pronto, tales crónicas no son escasas. Los estudiosos suelen respetar una lista asociada con una cronología determinada. De un total de cerca de treinta crónicas censadas, las más destacadas serían las siguientes -el año precede al título-:

634.- La Doctrina Iacobi, las enseñanzas de Santiago, texto cartaginés fuertemente anti-judío.

639.- La Crónica de Sofronio, patriarca de Jerusalén.

642.- El papiro PERF 558, escrito en griego y parte en árabe; probablemente el más antiguo texto conservado en árabe. La información en griego habla de tributos a los magharitae y sarracenos.

648.- La Vida de Gabriel de Qartmin, monasterio en la actual Turquía, en la que se cita a los ocupantes como hijos de Agar.

655.- Crónica del papa Martín I -raptado por el emperador bizantino junto con Máximo el Confesor y muerto en Crimea en 655-.

659.- Las cartas de Ishoyahb de Adiabene -al sur del lago Van-, que citan en siríaco a los tayyaye -en posible relación con pueblos nómadas- $\mathrm{y}$, nuevamente, los mhaggre -emigrados-.

660.- Crónica armenia de Sebeos, en la que se explican las alianzas entre los hijos de Ismael y los judíos, por ser todos descendientes de Abraham.

662.- Máximo el Confesor, discípulo de Sofronio el de Jerusalén, que imputa a los judíos los desórdenes de la gente del desierto.

665.- El testimonio del papa copto de Egipto Benjamín I, que vivió la conquista persa de Alejandría, posteriormente la conquista bizantina -que le acarreó el exilio-, y fue restituido por los árabes en su puesto de papa alejandrino.

670.- Cartas del peregrino Arculf y las referencias en las crónicas de Beda el Venerable, con las alusiones a que se estaban removiendo los cascotes de la explanada del Templo en Jerusalén.

680.- Jorge de Reshaina, oponente de Máximo el Confesor -el ortodoxo defensor del monotelismo-. Le echa las culpas a Máximo de que la ira de Dios haya permitido que los árabes tomasen África y Chipre. Este Jorge de Reshaina, al igual que la su-

31 J. FLORI, El Islam y el fin de los tiempos. La interpretación profética de las invasiones musulmanas en la Cristiandad medieval, Madrid, 2010, p. 80. 
puestamente hispánica Crónica Mozárabe -que veremos más adelante- aluden a los árabes, o caldeos o ismaelitas, como consecuencia de un desorden, y no como causa del mismo ${ }^{32}$. El implacable ataque de Jorge hacia el monotelismo de Máximo ubica ese tiempo de invasiones en un segundo plano, como si fuera una acción secundaria, un entorno tristemente conocido desde la evidente disgregación de Roma.

680.- El Apocalipsis judío atribuido -con cierta dificultad, todo sea dicho- a Simon Bar Yohai -coetáneo de la destrucción del Templo en el 70 de nuestra era, de ahí la dificultad- en que presentaría a los hijos de Ismael como la señal de que Israel accederá pronto a su salvación. Como es bien sabido, lo importante de toda falsificación no es en sí a quién se atribuye, sino cuanto implica en el tiempo de hacerse pública tal falsificación. En este caso, lo significativo es el descubrimiento de un vetusto Apocalipsis judío a finales de los 600, atribuyendo consideraciones salvíficas al desorden ocasionado por los hijos de Ismael -la tropa montada en asnos precederá a la de los camellos...-, en concordancia con la frenética actividad de desempolvar -o re-elaborar- las profecías atribuidas a Daniel, Elías, Enoch, Moisés, Zerubabel, o este Bar Yohai ${ }^{33}$.

680.- El Bundahishn o Creación primera, la enciclopedia zoroastriana escrita en pahleví, habla de los tayikos y su heterodoxia.

681.- Los Trofeos -en realidad, logros, victorias-obtenidos contra los judios de Damasco, crónica griega anti-judía que presenta un supuesto testimonio de primera mano de los ataques de los sarracenos, explicándolos como parte de una alianza de clanes judíos contra los bizantinos ${ }^{34}$. El autor, monje iconófilo, enmarca su ataque en la polémica iconoclasta -de hecho, ¿cómo distinguir a un iconoclasta cristiano de uno judío o proto-musulmán, en esos tiempos?-.

687.- Atanasio de Balad, patriarca de Antioquía, describe en una carta determinadas irregularidades orgiásticas en que mujeres y hombres toman parte, siguiendo los sacrificios rituales de los agarenos ${ }^{35}$.

687.- Juan Bar Penkaye, al final del libro 14 de su Síntesis de la Historia del mundo escrita en siríaco, comienza a relatar los hechos de su tiempo -continuará en el libro 15-. En ese colofón del libro 14, Bar Penkaye habla de los hijos de Agar en la tierra de los persas y de cómo vinieron por orden de Dios y dominaron todo no mediante la guerra y las batallas, sino de un modo más sutil. Como cuando se toma un hierro y se saca del fuego... ${ }^{36}$.

694.- La crónica del obispo copto egipcio Juan de Nikiu, describiendo la situación como la justa venganza divina por los pecados de Calcedonia -el Concilio que tuvo lugar en 451-. A lo que podríamos añadir las descripciones del Apocalipsis siríaco

32 M. LEVY-RUBIN, "The Role of the Judaean Desert Monasteries in the Monothelite Controversy in Seventh Century Palestine", J. PATRICH (ed.), The Sabaite Heritage in the Orthodox Church from the Fifth Century to the Present, Lovaina, 2001, p. 288.

33 B. LEWIS, "An Apocalyptic Vision of Islamic History", Bulletin of the School of Oriental and African Studies 13, 2 (1950), p. 308.

34 A. L. WILliAMS, Adversus Judaeos. A Bird's-Eye View of Christian Apologiae Until the Renaissance, Londres, 2012 ( $1^{\mathrm{a}}$ edic., 1935), pp. 162 y ss.

35 D. M. FRIEDENREICHT, "Muslims in Canon Law, 650-1000”, D. THOMAS y B. ROGGEMA (eds.), Christian-Muslim Relations. A Historical Bibliography, (Vol. I, 600-900), Leiden, 2009, p. 91.

36 S. BROCK, "North Mesopotamia in the Late Seventh Century: Book XV of John Bar Penkayé's Rish Melle", Jerusalem Studies in Arabic and Islam, 9 (1987), pp. 51-75. 
del Pseudo-Metodio, describiendo la llegada de los pueblos de Gog y Magog -igualmente denostada en el imaginario judeocristiano que en el islámico, y apareciendo posteriormente, de hecho, en el Corán como una plaga-, o incluso otro Apocalipsis siríaco, esta vez el del Pseudo-Efraím, describiendo como profecía que un pueblo se alzará desde el desierto: la descendencia de los hijos de Agar...

$* * *$

La cuestión se nos antoja harto compleja: en esas crónicas se percibe con claridad que todos atienden a que pasa algo. Cada uno lo describe en la clave apocalíptica que mejor se amolda a su percepción de los hechos. De acuerdo, pero: ¿en qué debemos basarnos para comprender ese tiempo de desastres como un único proceso inducido, dirigido por una sola fuerza invasiva con centro en Meca, Medina, Damasco...? Y otro pero: ¿por qué se traduce indefectiblemente por musulmanes cada vez que uno de esos pueblos aparece en las crónicas? Frente a la verborreica claridad interpretativa del mito, esos numerosos invasores parecen presentarse mudos, a la espera de su voz en árabe un siglo después. Tan mudos como aquellos viejos Pueblos del Mar en el segundo milenio antes de nuestra era, e igualmente difusos en su caracterización. Solo se sabrán y se contemplarán como uno solo -una sola fe, un solo estado- a posteriori; cuando aparezcan las crónicas árabes y recapitulen recolectando, a beneficio de inventario legitimador.

Y recalquemos eso de los numerosos invasores: no se trata de cuantificar la llamada profética del desierto, sino de leer en clave lógica y maximalista el enorme constructo mítico minimalista. En todas esas crónicas, a los pueblos causantes de los desórdenes se les denomina de estos modos diversos: tayyaye -en la zona armenia, en relación con los pueblos tayikos-, sarracenos, árabes, agarenos, ismaelitas, asirios, caldeos, magaritai/mahghraye -inmigrantes en siríaco, relacionados con la palabra árabe semejante: hiğra, éxodo-, etcétera. No vamos a recargar este texto con los numerosos estudiosos que han analizado tales crónicas -ya lo hacemos en otro lugar ${ }^{37}$-, y quedémonos solo con una relativamente reciente parada y fonda, para lanzar una pregunta con Hoyland ${ }^{38}$ como referencia, para el acceso a las fuentes primarias: ¿por qué no aparecen, ni una sola vez, los términos islam, musulmán o Corán?

\section{LA SENSACIÓN BIZANTINA}

La creciente pérdida de soberanía romana y cristiana en el Mediterráneo -muy especialmente desde los años 500- se tiende a explicar con numerosos factores en el norte, y solo uno -jinvasión!- en el sur. En clave apocalíptica, se tiende a abrazar todo el largo proceso como el castigo divino a indeterminados méritos pecadores.

37 E. GONZÁLEZ FERRÍN, "711, Historiología de una conquista”, Actas del Congreso "Al-Andalus y el mundo árabe (711-2011): Visiones desde el arabismo», Granada, 22-23 de septiembre de 2011 (67-90).

38 R.G..HOYLAND, Seeing Islam as Others Saw it. A Survey and Analysis of the Christian, Jewish and Zoroastrian Writings on Islam, Princeton, 1997. 
Por entre textos apocalípticos re-elaborados y cantos de cisne expedicionarios romanos, hay un hecho innegable: la percepción de un caos generalizado es previa al surgimiento del Islam. Apuntaremos que, precisamente, será el Islam la consecuencia final, el decantado de todo ese proceso, frente a su clásica consideración como causa.

Junto a esa percepción de caos generalizado, es igualmente innegable el trasvase de poblaciones huyendo de zonas conflictivas concretas; trasvase que da fe de algo no suficientemente resaltado en la vida mediterránea: el continuo intercambio y contacto de poblaciones. Como suele afirmar el profesor Ruiz Souza, los conceptos y las formas siempre viajan, pero no necesariamente juntos. Tampoco lo hacen normalmente -añadimos- en viajes de placer. Por ir adelantando materia, el gran hecho diferencial de lo andalusí será su progresiva arabización e islamización. Pero: ¿necesariamente viajaron juntas?

Volviendo a los traslados de poblaciones en el Mediterráneo: ya reseñaba Jerónimo aquello de "occidentalium fugium et sanctorum locorum constipatio" 39 -la huida de los occidentales y su concentración en los Santos Lugares-. El flujo de exiliados de Oriente a Occidente sería permanente. Y también viceversa: a Occidente huirían orientales como el obispo Qodvultdeus, comunidades enteras espantadas ante la inestabilidad provocada por el ir y venir de contingentes norteafricanos, principalmente vándalos en los 400. También de más allá, como el representativo Juan de Tabennesi -proveniente de los cenobios de Pacomio en el Valle del Nilo ${ }^{40}$, cuya llegada a Europa a finales de los 400 ilustra el encendido debate cismático que vivía el Mediterráneo. Por su parte, el papa Hormisda (m. 523) -italiano de nombre persa, para ilustración del viaje de ideas en los siglos; expulsor de los maniqueos de Roma- incluye noticias de la llegada de numerosos hombres de religión orientales que desembarcaron en las costas de Hispania, preocupándole su limpieza de sangre calcedoniana. Esto es: consciente de la resistencia a una ortodoxia derivada de determinados cánones -absolutamente catalizadores de herejías- incluidos en el concilio de Calcedonia de 451, al papa le preocupa el limo herético que pueda formarse en Hispania.

En las crónicas de la época, las gentes huyen por igual de ortodoxias que de hunos o godos -tras la retirada del Imperio Romano de la Galia- o de persas. Un momento esencial será la Renovatio Imperii de Justiniano, o esa debacle bizantina en Oriente Medio a principios de los 600: huirán a Occidente alejándose de los actos de violencia de la Persia Sasánida. También cruzarán a Hispania. Citando textualmente a Margarita Vallejo, "los monjes africanos se refugiarían en España huyendo de las razzias que los moros -maures, en el original francés- llevaban a cabo en territorios africanos, gobernados aún por el Imperio”, situación nada anormal, dado que "ya en el transcurso del siglo VI, numerosos africanos buscarían refugio en Sicilia y otras islas de Italia huyendo de las razzias de los moros y

39 M. VALLEJO GIRVÉS, “Constantinopla como residencia forzada”, M. CORTÉS ARRESE (coord.), Elogio de Constantinopla, Cuenca, 2009, p. 32.

40 P. D. SCOTT, Paganism and Christianity in Egypt, Cambridge, 2010 (1 ${ }^{\mathrm{a}}$ edic., 1923), p. 211. 
del rebelde Stotzas" ${ }^{41}$-amotinado bizantino asociado al rey moro Antalas en 544-. ¿Realmente debemos aplazarlo todo al 711, o podríamos entenderlo como la gota que derramó el vaso?

\section{$* * *$}

Desde luego, es una sorpresa encontrarse con testimonios de razzias de moros tan antiguas, que acabarán constituyendo un mismo totum revolutum desde finales de los 500, en que la Europa mediterránea debe sufrir los forzosos movimientos de población relacionados con las incursiones godas, eslavas, lombardas -en el norte de Italia- y avaras en Oriente ${ }^{42}$. Por cierto, que a estos pueblos sí los citan las crónicas por sus nombres, y no por el que después pudiera parecer más correcto a los traductores con respecto al sur.

En torno al 620, también se producirían movimientos forzosos de población desde Hispania hacia la Galia, respondiendo al trato que Sisebuto deparó a los judíos, según el testimonio de Isidoro de Sevilla -nada pro-judío, todo sea dicho ${ }^{43}$-, y simultáneamente desde el Oriente mediterráneo al norte de África. En este sentido, resulta ilustrativo el caso de Juan Mosco ${ }^{44}$ y su discípulo Sofronio -futuro patriarca de Jerusalénhuyendo a Roma en torno al 620, o el de Máximo el Confesor a Cartago, huyendo de la presión persa sobre Constantinopla por las mismas fechas. Este ambiente protoapocalíptico no entiende de discontinuidades: todo es un mismo proceso de castigo por nuestros pecados, ya sea tanto a manos de los ávaros como de los sarracenos.

Hay buenos trabajos sobre la diáspora bizantina debida a los persas y el concepto del nómada para Bizancio ${ }^{45}$; pero nos resultan especialmente aclaratorios y cercanos los de Vallejo Girvés acerca del miedo de una época, la sensación bizantina de pérdida, previa a la ganancia islámica -producto de la anterior, apostillaríamos nosotros-. La autora describe con claridad la transposición del miedo al persa y su reubicación como miedo al agareno: en todo Oriente Próximo y Medio se conocían las tácticas persas de deportaciones de pueblos enteros ${ }^{46}$, y podemos recuperar dos sensaciones de aquel convulso tiempo sin las cuales no se comprenderá la facilidad de eclosión islámica: por una parte, el dato ya destacado de que Persia había tomado Jerusalén en 614. Por otra parte, que toda esa región conoce desde siempre los saqueos de los sarracenos. La gran sorpresa en 638 es que, en contra de su natural costumbre de razzia y huida, los sarracenos se quedan.

41 M. VALLEJO GIRVÉS, “L'Europe des Exilés des Derniers Siècles de l'Antiquité Tardive (Ve-VIIe siècles)”, P. MARCILLOUX (dir.), Les Hommes en Europe, París, 2002, p.162.

42 V. NERI, I Marginali nell' Occidente Tardoantico. Poveri, 'Infame' e Criminali nella Nescente Società Cristiana, Bari, 1998, pp. 190-192.

43 S. KATZ, The Jews in the Visigothic and Frankish Kingdoms of Spain and Gaul, Cambridge, 1937, pp. 11-12.

44 J.S. PALMER, Historias bizantinas de locura y santidad, Madrid, 2001, pp. 10-14.

45 H. AHRWEILER, "Byzantine Concepts of the Foreigner: the Case of the Nomads", H. AHRWEILER y A. E. LAIOU (eds.), Studies on the Internal Diaspora of the Byzantine Empire, Washington, 1998, pp. 1-17.

46 M. VALLEJO GIRVÉS, "Sensaciones bizantinas: las dos caídas de Jerusalén en la literatura del siglo VII", Erytheia, 27 (2006), p. 45. 
Efectivamente, durante siglos, las tribus pobladoras del Próximo Oriente habían campado por sus respetos en unas ocasiones, y en otras habían engrosado las filas de alguno de los dos Imperios en liza -o de los dos, según y cómo-, Bizancio y Persia. Las referencias a la historia de los sarracenos son mucho más interesantes en estado puro que a través de su disfraz imperial en las crónicas ortodoxas. Benjamin Isaac trae a colación numerosas fuentes rabínicas y bizantinas que arrojan luz suficiente para lo que podemos describir como siglos de improvisación frente al determinismo profético en que tendemos a colorear una época en llamas ${ }^{47}$. El precedente de tribus sarracenas confederadas para golpear aldeas, monasterios y ciudades nos lo ofrece el año 378 con la revuelta de la reina árabe siria Mawiya -ni siquiera entraremos en cuanto podría significar esa fonética Mawiya para las crónicas árabes que fijarán la unificación del califa Mu awiya, ausente en las crónicas primeras-, y desde entonces los árabes no sólo eran conocidos, reconocidos y temidos en su zona, sino que llegaron a controlar en nombre de Bizancio -a partir de Justiniano- la frontera oriental del Imperio ${ }^{48}$. El mismo papel que los visigodos desempeñaban en Hispania.

Árabes al servicio del Imperio, árabes que el Imperio debe reprimir. En su Crónica, Sofronio quiere que las tropas imperiales sometan la loca arrogancia de los sarracenos, para asi humillarlos bajo los pies del emperador, como antes -en negrita nuestra ${ }^{49}$-: ¿qué antes? ¿no eran antes los persas los enemigos del Imperio? ¿no serán los sarracenos de siempre a los que ve Sofronio, y no a ese mundo alienígena de las crónicas muy posteriores, foráneos reunidos en torno a una suerte de hormiguero del desierto?

El poderoso limes arabicus ${ }^{50}$ era una zona de clara inseguridad y de orgánica expansión: mientras el Imperio Persa entraba en Jerusalén en 619 y después en Alejandría, los monjes del monasterio de Santa Catalina (Sinaí egipcio) eran masacrados por tribus sarracenas ${ }^{51}$ : resulta evidente la coexistencia del peligro árabe con el aún efectivo bizantino, así como el carácter preislámico de estas correrías. La sorpresa de los estudiosos se centra en un aparente cambio de táctica: los sarracenos -agarenos, árabes, etc.- siempre atacaban, arrasaban y huían. Pero a partir de 638 ya se quedan. La cuestión es: en sus razzias habituales ¿realmente solían irse siguiendo costumbres ancestrales, o porque podían venir a por ellos las tropas imperiales? ¿realmente es una sorpresa, cuando ya no hay en todo Oriente Medio tropas imperiales -ni bizantinas ni persas-, que esos asaltantes habituales cambien de táctica? Por otra parte, ¿cuesta tanto sospechar que las tropas árabes incorporadas al Imperio bizantino, controladoras de la frontera oriental, campasen por su respeto cuando Constantinopla ya se replegase del Próximo Oriente tras aquella victoria pírrica sobre Persia en Nínive?

47 B. ISAAC, "Bandits in Judea and Arabia”, Harvard Studies in Classical Philology, 88 (1984), pp. 193195.

48 M. VALLEJO GIRVÉS, op. cit; 2006, p. 55.

49 J. FLORI, op. cit; 2010, p. 100.

50 B. ISAAC, op. cit; 1984, p. 194.

51 Ibidem, p. 196. 
Finalmente, y considerando que esas tribus sarracenas atacaban habitualmente, en simultaneidad con los movimientos de otras tribus sarracenas incorporadas al ejército bizantino, ¿realmente debemos esperar a una llamada profética en 622 para ver árabes que suben hacia el Próximo Oriente desde el sur?

\section{LA EXPLICACIÓN DEL ISLAM Y LAS CRÓNICAS HISPANAS}

Consideramos que no hay una explicación clara y contundente para el Islam, sino que el Islam es la explicación; el decantado de un tiempo. Por lo mismo, entendemos -según se leen las crónicas y testimonios de la época- que no hay un Imperio islámico hasta la fundación de Bagdad, que no trepan los creyentes por el mapa de Oriente Medio y se extienden hacia Occidente acabando con dos imperios, sino que las poblaciones habituales se hacen fácilmente cargo de la situación al no haber imperios que controlen o repriman su expansión. En base a lo anterior, nos movemos en la hipótesis de que el Islam no es la causa de cuanto pudo pasar entre finales de los 600 y mediados de los 700 en el Mediterráneo, sino que fue consecuencia de cuanto venía pasando.

Existe otro asunto que debe relacionarse con lo anteriormente expuesto: en ningún caso habla cronista alguno acerca de algo considerable como la religión islámica. Apunta Vallejo Girvés que "los teólogos bizantinos tardaron tiempo en darse cuenta de que la religión que traían los árabes era algo más que una nueva herejía [...]"52. La puntualización es realmente certera, y puede contemplarse desde otro punto de vista, aplicando el cambio de paradigma que hemos descrito en la interpretación sobre los orígenes del islam como religión: puede que no trajeran religión nueva, sino que todo estaba aún en plena cocción, y por eso nadie acierta a reconocerla de inmediato. Huelga decir que nos movemos en una interpretación de lo teológico que se basa en el concepto de desarrollo, evolución, y no en el de transmisión. No creemos que pueda sostenerse la historia de los sistemas religiosos como custodia de legados proféticos, sino que estos van decantándose con los siglos.

Efectivamente, desde Sofronio en 639 hasta Juan Damasceno en 750 se desarrolla un siglo de simbiosis creativa en materia religiosa. Resulta significativo, por ejemplo, que los cronistas prefieren, durante largos decenios, atacar a los judios $[\ldots]^{53}$, algo que puede apuntarse con fiabilidad documental. En las crónicas se alude sistemáticamente al colaboracionismo judío, al control judío de ciudades, etc. ¿Es realmente una preferencia, un anti-semitismo cronístico espontáneo, o la absoluta incapacidad de distinción entre mil y una formas de ser judeocristiano en esos siglos -monoteísta sin etiquetados simplistas-? Obsesionados por la taxonomía, la inercia de cuanto pensamos que siempre ha sido un sistema religioso determinado nubla la realidad de cuanto realmente debe entenderse como complejo ensayo $y$ error -simbiótico y antibiótico- de unas religiones en continua evolución.

52 M. VALLEJO GIRVÉS, op. cit; 2006, p. 57.

53 Ibidem, p. 58. 
La interpretación apocaliptica del desmembramiento de Bizancio incluida en las crónicas de los siglos previos a Bagdad nos muestra unos cambios de tonalidades e intencionalidades significativos. Desde la inicial apocalíptica judeocristiana enfrentada a la Roma imperial -basada en que Roma es la nueva Babilonia tras la cual llegará el final de los tiempos-, se va cambiando el punto de mira. Por decirlo brevemente: los cronistas cristianos -no necesariamente los judíos- dejan de vilipendiar a Roma a partir de la simbiosis entre esta y la cristiandad, ejemplificada en el giro de Constantino; aprovechamiento del cristianismo populista como ideología de Estado, y orientalización del Imperio con el traslado de capitalidad a Constantinopla, principios de los 300. A partir de entonces, los cronistas siguen obsesionados con el fin del mundo, pero desligado de lo estrictamente romano. Surgirán entonces las acusaciones de impiedad, de herejía, de laxitud de conducta, etcétera. Resumiendo: a los cronistas apocalípticos cristianos les interesaba desconectar a Roma del Fin del Mundo, y los tiempos convulsos encontrarán nuevos enfoques, nuevos bárbaros.

Ese cambio de punto de mira es lento, pero se inicia antes incluso del año 400, por lo que es imposible relacionarlo con causa islámica alguna -de nuevo: Islam como consecuencia, no como causa-. Ya el donatista Ticonio, hacia 380, alude a las desastrosas profecías de Daniel para apuntar que "lo que menciona Daniel, está a punto de realizarse hoy en África" ${ }^{54}$, en alusión a la inestabilidad política y social de un tiempo que continuamente provoca movimientos de población en el Mediterráneo. A finales de los 500, Isidoro de Sevilla alude a los hunos como plaga en las manos de Dios, y se ve obligado a citar a los hijos de Agar, llamados agarenos y últimamente sarracenos ${ }^{55}$. De nuevo: ¿hay que esperar al Profeta para percibir la naturalidad caótica de unos pueblos, en modo alguno distinguibles de hunos, avaros y tantos otros en su nomadismo salteador?

Solo en ese ambiente de ideas y consideraciones podrá acabar arraigando la unificación interpretativa de la descentralización romana en términos de invasión única y organizada, a la postre llamada Islam. Dado que el Islam existe a mediados de los 800 , y dado que no se ha seguido una secuencia cronística lógica para su existencia como tal, como civilización sorprendentemente árabe, se reinterpretarán las crónicas del desorden como crónicas de invasión. De la explicación maximalista, a la minimalista. El aval definitivo de tal impostura serán las triunfalistas crónicas árabes a partir de esos tiempos, obsesionadas con la justificación abbasí: la coherencia lineal de una llamada profética.

$$
* * *
$$

En el paso de la Antigüedad Tardía a la Edad Media, resulta evidente la interpretación de los acontecimientos de la historia a la luz de la Biblia. Esa pedagogía divina ${ }^{56}$ se centra en el peligro persa ante la evidencia de su amenazante vecindad con Roma -la nueva Roma, Constantinopla-, aderezada con cromáticos episodios

54 J. FLORI, op. cit; 2010, p. 80.

55 Ibídem, p. 89.

56 Ibidem, p. 97; J. TOLAN, op. cit; 2007, p. 15. 
de tal enfrentamiento, como el robo de la vera cruz en 614, su traslado a Persia, la heroica restitución de Heraclio. La pedagogía divina insufla toda la cronística que asistirá al desmembramiento de Oriente Medio, el Mediterráneo sur e Hispania, y no acertará a interpretarlo de otro modo. Llegado el tiempo en que múltiples pueblos controlen diversas ciudades mediterráneas y orientales, los cronistas seguirán su tónica. Flori lo describe a la perfección: "la zona no experimentó los hechos como algo fundamentalmente excepcional, sino como una calamidad más que se unía a todas las anteriores" $" 57$.

Todos están de acuerdo en que cuanto viene produciéndose -inconexo, improvisado- en todo el Mediterráneo es un castigo divino, "pero disienten o difieren en designar a los culpables" ${ }^{58}$. Numerosos cronistas apuntarán que los judios han empujado a los sarracenos a rebelarse -buen enfoque este, el de la rebelión-, y desde Sofronio, obispo de Jerusalén, hasta Arculf el Peregrino, se asiste a un neojudaísmo costumbrista en Oriente Próximo, como en el célebre testimonio de que los judios están removiendo cascotes en la explanada del Templo. Esas obras en la explanada del Templo -que la historia posterior contempla claramente como erección de la Cúpula de la Roca-, se percibe en su tiempo como abominación de la desolación profetizada por Daniel como signo del fin de los tiempos ${ }^{59}$. Unos judíos reconstruyen el Templo, pero las crónicas posteriores traducen a su modo, conocedoras del capítulo siguiente en la Historia.

Surge aquí un problema esencial: si realmente esas obras se corresponden con el inicio de la construcción de una mezquita ordenada por un califa, tal y como se asume dogmáticamente, ¿por qué no hay evidencias documentales? Resulta evidente que hasta los tiempos de Juan Damasceno (m. 750) -prolífico en griego, en un tiempo en absoluto arabizado más allá de unas monedas e inscripciones-, es decir, hasta el eclipse de lo que supuestamente fuera un Imperio Omeya de Oriente, nadie reconoce a nadie en ese tiempo de forja de civilizaciones y religiones. Los interlocutores judíos de Jacobo de Sarug le llegan a preguntar si ese profeta que ha surgido entre los sarracenos será el Mesías: Jacobo les dice que no, pero ya tenemos al componente que se necesitaba en toda esta escatología cronística: la consideración de este profeta irá cobrando forma desde este tiempo, pasando por las pinceladas de Juan Damasceno -curiosas, dado que se le supone afín al poder en Damasco, y se permite menospreciar las creencias de los sarracenos, dejando testimonio de que aún no había un Corán codificado- y llegando a similares consideraciones en Eulogio de Córdoba a mediados de los 800, sorprendido por los cambios de los tiempos ${ }^{60}$, pero sin alusiones directas a pasadas invasiones o conquistas. Ese es el tiempo de forja del Islam, y el arranque de una retroalimentación cronística.

57 J. FLORI, op. cit; 2010, p. 99.

58 Ibidem, p. 101.

59 B. FLUSIN, “L' Esplanade du Temple à l'Arrivée des Arabes, d'après Deux Récits Byzantines", J. RABY e I. JOHNS (eds.), Bayt al-Maqdis, Oxford, 1992, pp. 25-26.

60 P. HERRERA ROLDÁN, "Sobre monjes y literatura monástica en la Córdoba emiral", Meridies, 7 (2005), p. 9. 
En definitiva, las crónicas ofrecen una lectura escatológica del desorden, y solo posteriormente se contemplará la solución minimalista de una invasión organizada. Es en ese contexto en el que se redactan las dos únicas crónicas supuestamente hispánicas relacionadas con los desórdenes, los sarracenos y el fin de los tiempos.

$$
\text { *** }
$$

Así como el Oriente romano avanza lentamente hacia el Islam, en similar incertidumbre y mudez de protagonistas se decanta Al-Andalus, progresivamente, desde Spania -la franja orientalizada por Bizancio- y el eclipse de Hispania. Lo hace en una larga franja temporal que va desde el colapso de la monarquía visigoda en 710 -verdadero detonante de la arabización e islamización de la Península-, hasta la constatación de problemas sociales en los 800 , derivados de un orden mayoritario determinado, con revueltas en Córdoba y el movimiento de los llamados mártires de la misma capital-. Tal progresivo decantado depende de una continuada orientalización de la Península Ibérica; unas oleadas más en la continua marea orientalizante que explica la presencia en tales tierras de fenómenos sociales como el cristianismo, el judaísmo, y todas las posibles e imposibles corrientes intermedias. También será un hecho la permanente traslación de poblaciones a través del Estrecho de Gibraltar, tanto de norte a sur como viceversa.

Pero cuanto pasase por el Estrecho -continuas migraciones- y cuanto entrase por la costa levantina -desembarcos bizantinos- no tienen necesariamente una relación directa, menos aún asociada a un indeterminado estado islámico con capital en Damasco, aún en proceso de arabización -desde lo helénico bizantino oficial- y por cuyas brumas de precariedad institucional, comenzaba a vislumbrarse la acuñación de moneda en árabe desde principios de los 700. Por otra parte, debe resaltarse la forja de Al-Andalus desde dentro, por mucha incorporación de elementos orientales que esto conlleve -insistimos, en la misma línea que siglos anteriores-. En este punto, deben traerse a colación varios matices, siempre desdeñados en los estudios al respecto -ante la comodidad interpretativa del mito invasor-, como que el colapso de la monarquía visigoda es un hecho interno, derivado de problemáticas sociales y religiosas -como el enfrentamiento entre la Iglesia y la Corona, patente desde mediados de los 600. No hace justicia historiográfica resolver el problema de la monarquía visigoda con el plumazo de una invasión. Por otra parte, y en paralelo, hasta mucho después de las fechas que nos ocupan, el judaísmo mediterráneo se expandió por conversión. Algo que debe destacarse, so pena de seguir anclados en el mito de la raza o la transmisión genética del Pueblo Elegido: la expansión del judaísmo es también la del islam.

$\mathrm{Si}$ a eso le sumamos la panoplia de movimientos marginales, heterodoxos y/o heréticos en el arco posible judeocristiano mediterráneo, ¿cómo distinguir a un postadopcionista de un pre-musulmán, en la Península Ibérica de mediados de los 700 -por poner un caso-? Desde las diatribas de los 500 entre arrianos y romanos, las conversiones de ida y vuelta del judaísmo, hasta la anatematización romana del adopcionismo hispano, el problema religioso peninsular, sumado a la descentralización creciente de una Corona visigoda, en franca fase de deslegitimación, se hará difícil 
distinguir causas y efectos en el surgimiento de un nuevo orden hispano: Al-Andalus. Entre nuevos actores, pugnas por el poder, y condensación de un nuevo orden mediterráneo -aún en proceso-, las revoluciones ibéricas, al igual que aquellas orientales, serán tomadas por conquista a posteriori, las inmigraciones forzosas -como hacia Francia-, serán consideradas extensiones de invasiones. Frente a este estado de cosas peninsulares, en modo alguno diferente -si bien específico- con respecto al resto del decantado islámico mediterráneo, al otro lado de los Pirineos se vivía una evolución diferente, en posterior filtración neo-gótica por el norte peninsular. La coincidencia de estos acontecimientos con la fundación del Sacro Imperio Romano -mediante la coronación de Carlomagno-, y el intento de control carolingio sobre el Valle del Ebro (777), así como el posterior cierre peninsular al no lograrlo -si bien con el norte diferenciado; no olvidemos el trato que Beato de Liébana dedica al citado Elipando de Toledo, obispo proto-islámico en sus planteamientos-, están en la base del decantado de Al-Andalus.

$$
* * *
$$

Existen dos tipos de testimonios fidedignos en el tiempo y espacio que nos ocupa: pruebas materiales como algunas monedas y precintos de plomo, y dos crónicas latinas. Con respecto a las monedas y precintos, nos tememos dos cosas: en primer lugar, que la lectura de leyendas e inscripciones depende en todo momento de la cronología y la narración oficial incluida en las muy tardías crónicas árabes. En segundo lugar, que al igual que ocurrió en el Damasco de Abdel Malik -finales de los 600-, la acuñación de moneda no implica orden imperial sino -probable y precisamenteindependencia. Por otra parte, una cosa es la aparición de monedas, y otra la certeza de dónde fueron acuñadas. La coexistencia de monedas con leyenda latina y mensaje proto-islámico, así como leyenda árabe y silencio teológico, tanto en Oriente como en Hispania, dificulta enormemente la fijación de fechas fundacionales.

El asunto de las crónicas es más ilustrativo. Las dos únicas crónicas que podrían contar en su haber con el hecho de ser fuentes primarias para la recapitulación de cuanto pudo ocurrir en la Península Ibérica de principios de los 700, son la llamada Crónica Arábigo-Bizantina de 741, y la llamada Crónica Mozárabe de 754. La primera de ellas, la de 741, siempre se ha transmitido como continuación del Chronicon de Juan de Biclaro (540-621) -viajero de Hispania a Constantinopla y vuelta-, o bien de las Historias de los Godos de Isidoro de Sevilla -de ahí que también se la conozca como Continuatio Isidoriana Byzantia-Arabica-. Estudiada por C.E. Dubler en 1946, siempre se le criticó su dictamen de filo-islamismo del autor; un posible hispano o africano, sumado a la corriente proto-islámica -pre-árabe, en cualquier caso-, y centrado en la historia de Bizancio y los sarracenos. Habla de Mahoma, príncipe de los sarracenos, desde Oriente, sin conexión alguna con la hipotética entrada en Hispania o Spania, y bebe de las fuentes siríacas orientales. Difícilmente podría ser su autor un converso al islam con amplios conocimientos de árabe ${ }^{61}$ : ¿qué textos podría haber leído en esa época, escritos en árabe? El tono bizantino lo sitúa en impecable

61 J.C. MARTÍN IGLESIA, "Los Chronica Byzantia-Arabica. Contribución a la discusión sobre su autoría y datación, y traducción anotada", E-Spania, 1 (2006), p.12. 
conexión con el resto de las crónicas orientales aquí tratadas, en enésima prueba de que todo el Mediterráneo estaba conectado, y percibía del mismo modo escatológico y apocalíptico los diversos desastres de los tiempos.

El problema de esta crónica es doble: por un lado, su intención de indicar que no es ningún deshonor para los vencidos, haber pasado a formar parte del nuevo Imperio que ha venido a sustituir al Romano y al que se somete el mundo entero ${ }^{62}$, ofrece la impresión de ser un texto muy posterior. Por otro lado, la fe en la crónica puede también ponerse en entredicho: los cuatro códices originales existentes, tres de ellos en España -Toledo, Segorbe y Madrid- y uno en Londres, fueron copiados a finales de los 1500. Y volvemos a lo de siempre: a esas alturas, ya se ha podido vender lo propio por ajeno.

La segunda de esas crónicas, mal llamada Crónica Mozárabe de 754 -su autor no estaba arabizado, ni mucho menos, que es lo que significa mozárabe-, da menos información aún que la anterior, pese a ser -supuestamente- posterior. No hace distinciones de religión: no habla de cristianos y musulmanes, sino de godos o francos frente a gres Ishmaelitarum o mauri -ya veíamos, los mismos citados desde siglos atrás-. Incluye extensos pasajes sobre batallas entre bizantinos y persas, comparados con David y Goliat. Es sensible al enfrentamiento entre Oriente y Occidente pre-islámico, y en ningún caso emplea términos como islam, musulmanes, Corán, etcétera. Sin embargo, se hace eco de debates hispanos sobre la Santísima Trinidad. De nuevo: otra crónica mediterránea más.

Poniendo en relación la fecha del códice y su nombre, nunca hemos comprendido por qué no se la conoce, sin más, como Continuatio Hispana de 850, habida cuenta de la fecha más temprana de los ejemplares existentes ${ }^{63}$. Al margen queda el posible completo stemma de estos códices, su árbol genealógico. Como sintetiza su editor Juan Gil, "ante una transmisión en estado tan ruinoso como la de aquella Crónica, ¿quién era el guapo que asegurase cuántos hiparquetipos habia habido de verdad? Entonces, ¿a qué aventurar certezas, en un campo donde lo que reina es, precisamente, la incertidumbre?" 64 .

El resbaladizo texto de esta Crónica Mozárabe ${ }^{65}$, no comenta una invasión en nombre del islam, y sin embargo pasa revista a otros acontecimientos peninsulares de su tiempo. Recoge que en 721, un tal Sereno proclamó ser el Mesías entre sus correligionarios judíos. Que en 744, el obispo Cixila curó a alguien de la herejía sabeliana. Que en 750, el abad Pedro de Toledo escribió un libro para los cristianos de Sevilla que celebraban la Pascua en una fecha equivocada. Wolf sentencia acertadamente: "resulta interesante que un cristiano hispano debería haber encontrado estas tres aberraciones religiosas de menor interés para su reseña, en tanto ignora completa-

\footnotetext{
62 Ibídem, p.13.

63 J.E. LÓPEZ PEREIRA, Continuatio Isidoriana Hispana. Crónica Mozárabe de 754, León, 2009, p.

64 J. GIL, "Discursos pronunciados en la solemne investidura de Doctor Honoris Causa del Excmo. Sr. D. Juan Gil Fernández”, Cuadernos de Filología Clásica. Estudios Latinos, 28, 1 (2008), p. 160.

65 C. CARDELLE DE HARTMANN, "The Textual Transmission of the Mozarabic Chronicle of 754", Early Medieval Europe, 8, 1 (1999), p. 13.
} 157. 
mente cualquier referencia al islam "66. Esta crónica se inscribe en el mismo ambiente apocalíptico mediterráneo que la anterior y todas las que hemos visto de Oriente.

Por otra parte, todas estas crónicas no son sino palimsestos: la Crónica Mozárabe de 754 presenta similitudes con la francesa de Fredegar en 650 -con numerosos añadidos muy posteriores-. Ambas incluyen pasajes de viejas crónicas previas, con noticias entresacadas de obras de Isidoro de Sevilla. En el caso de la de Fredegar, por ejemplo, se asume que es imposible entresacar lo correspondiente al 650 de entre la maraña de añadidos. Sin embargo, en la Mozárabe se afirma su cronología con exactitud. En ambas tradiciones, la referencia a Poitiers, por ejemplo, se lee en clave bíblica, con la palabra latina para combatientes -belligerantii-sacada del Libro de los Macabeos, y apodándose al vencedor Carlos Martel de esta guisa -Martellus, martillo-, en probable traducción del sobrenombre de Judas Macabeo -martillo-, héroe del no pasarán judío frente a los paganos orientales, y en cuyo honor se celebra la fiesta de la Hanukká. Tema este, el de la expansión del imaginario judío, que arrojaría luz suficiente para comprender la expansión del islam por el Mediterráneo así como el exacto contexto de estas crónicas.

En definitiva, el islam, en tanto que sistema religioso, surge y se forja en las hendiduras entre ortodoxias bizantinas y numerosas disidencias. En paralelo, la consideración invasiva, genérica y unitaria del Islam es un constructo apocalíptico cristiano medieval, previo en todo caso a la existencia de crónicas árabes, pero siempre posterior al testimonio de razzias sarracenas en Oriente Próximo. Tal consideración invasiva se forja progresivamente, desde la sorpresa pre-mahometana del desmembramiento imperial romano en torno a los 400 de nuestra era, hasta el reconocimiento histórico del Islam como civilización, con la fundación de Bagdad después de 762. Esto deja por el camino varios mitos:

- El sentido creacionista del Islam invasivo.

- La consideración del tiempo omeya oriental como Imperio islámico.

- La expansión hasta Hispania como parte organizada de tal hipotético Imperio.

En tales condiciones, debe asumirse que el Islam, como lento decantado civilizador, es la consecuencia de cuanto azotó al Mediterráneo desde los 400 a los 800, y no la causa de un desastre sobrevenido en 711.

66 K. B. WOLF, “The Earliest Spanish Christian Views of Islam”, Church History, 55 (1986), p. 283. 